\title{
DIGITALISASI PRODUK UNGGULAN DESA SUKAMAJU KECAMATAN CIHAURBEUTI KABUPATEN CIAMIS BERBASIS QR CODE DAN FACEBOOK MARKETPLACE
}

\author{
Irfan Nursetiawan*, Kiki Endah, Ii Sujai \\ FISIP Universitas Galuh \\ *Email: irfan.nursetiawan@gmail.com
}

\begin{abstract}
ABSTRAK
Masyarakat prasejahtera di Desa Sukamaju Kecamatan Cihaurbeuti Kabupaten Ciamis masih sangat dominan, dimana masih banyak didominasi oleh kaum petani dan buruh tani, serta tidak adanya kreativitas untuk menciptakan peluang usaha. Tetapi di desa tersebut terdapat beberapa produk unggulan desa yang dapat dikembangkan menjadi produk unggulan desa. namun terdapat beberapa hambatan dalam pengembangannya, salah satunya sulitnya untuk memasarkan produk unggulan desa tersebut. Sementara itu, solusi yang ditawarkan adalah melaksanakan kemitraan kepada para Usaha Mikro, Kecil dan Menengah (UMKM) produktif dan tergolong ke dalam masyarakat prasejahtera untuk membentuk kelompok usaha dan menumbuhkan semangat berwirausaha dalam rangka meningkatkan perekonomian keluarga. Selain itu, memaksimalkan keberadaan Pos Pemberdayaan Keluarga (Posdaya) dan Badan Usaha Milik Desa (BUMDes), serta mengimplementasikan pemanfaatan teknologi informasi, yaitu dengan membuat QR-Code dan akun Facebook Marketplace. Tujuan kegiatan pengabdian ini adalah menumbuhkan semangat berwirausaha bagi masyarakat perdesaan yang tergolong prasejahtera sebagai mitra melalui pembentukan kelompok usaha, serta memberdayakan potensi mitra dalam meningkatkan pendapatan keluarga melalui peningkatan usaha ekonomi kreatif berbasis teknologi informasi. Sedangkan target khusus dari kegiatan pengabdian ini, yakni dalam pengembangan ekonomi lokal dan wilayah adalah dengan terbentuknya kelompok usaha yang dapat mandiri secara ekonomi dan dapat meningkatkan pendapatan keluarga khususnya, serta dapat meningkatkan pendapatan ekonomi lokal dan wilayah pada umumnya. Kegiatan ini dilaksanakan selama 6 (enam) bulan, dimana terdapat beberapa tahapan kegiatan pada pelaksanaan Pengabdian Kepada Masyarakat (PKM) ini, antara lain: (1) evaluasi awal; (2) pembentukan kelompok usaha; (3) pelatihan pembuatan QR-Code; (4) pelatihan pembuatan Facebook Marketplace; (5) pendampingan manajemen usaha; (6) evaluasi akhir, dan (7) pemantauan khusus yang keberlanjutan. Kegiatan tersebut telah dilaksanakan, dan masyarakat desa mulai memanfaatkan Facebook Marketplace sebagai media promosi dan pemasaran produk, serta pihak BUMDes telah menyadari manfaat dari QR-Code sebagai bentuk identitas produk berbasis digital.
\end{abstract}

Kata kunci: Digitalisasi produk unggulan, $Q R$ Code, Facebook Marketplace

\section{PENDAHULUAN}

Desa pada saat ini tidak terlepas dari program pembangunan yang paling utama oleh pemerintah pusat dan pemerintah daerah. Begitu banyak permasalahan di wilayah perdesaan yang harus menjadi perhatian semua pihak dan para stakeholder. Adapun beberapa permasalahan yang muncul, diantaranya kemiskinan, kesenjangan, masalah sosial-politik, ideologi, dan bahkan sering terjadinya konflik sengketa lahan (agraria). Kesejahteraan masyarakat desa merupakan sebuah harapan dan cita-cita yang ingin diwujudkan oleh pemerintah pusat dan pemerintah daerah, guna menciptakan masyarakat desa yang madani.

Salah satu solusi yang dapat mewujudkan masyarakat desa sejahtera, yakni melalui pemberdayaan masyarakat. Hal tersebut sesuai dengan Undang-undang Nomor 6 tahun 2014 tentang Desa yang menyatakan, bahwa Pemberdayaan Masyarakat Desa adalah upaya mengembangkan kemandirian dan kesejahteraan masyarakat dengan meningkatkan 
Digitalisasi Produk Unggulan Desa Sukamaju Kecamatan Cihaurbeuti Kabupaten Ciamis Berbasis QR Code dan Facebook Marketplace Irfan Nursetiawan, Kiki Endah, Ii Sujai

pengetahuan, sikap, keterampilan, perilaku, kemampuan, kesadaran, serta memanfaatkan sumber daya melalui penetapan kebijakan, program, kegiatan, pendampingan, yang sesuai dengan esensi masalah dan prioritas kebutuhan masyarakat desa.

Berdasarkan hal tersebut, pemberdayaan merupakan salah satu cara dan upaya dalam peningkatan kesejahteraan masyarakat perdesaan. Begitu pula di Desa Sukamaju Kecamatan Cihaurbeuti Kabupaten Ciamis mempunyai potensi Sumber Daya Alam (SDA) yang banyak, tetapi belum dikelola dengan maksimal. Desa Sukamaju memiliki produk unggulan desa, diantaranya kopi, gula semut, dan kerajinan tangan yang masih bercirikan kerarifan loka desa setempat. Tetapi terdapat permasalahan yang paling mendasar dalam pengembangan dan pemasaran produk unggulan tersebut.

Uung dan Adril (2016), menyatakan bahwa permasalahan yang paling mendasar dalam pengembangan usaha adalah kurangnya akses pada sumber permodalan, pasar, dan teknologi, serta organisasi yang masih lemah, sehingga pengembangan produk unggulan daerah selalu tidak mulus dalam pelaksanaannya. Begitu pula yang terjadi pada produk unggulan Desa Sukamaju terdapat beberapa hambatan, diantaranya: (1) masih terbatasnya kegiatan produksi; (2) pemasaran produk yang masih terbatas; (3) kemasan yang masih bersifat konvensional; (4) peralatan belum mencukupi untuk kegiatan produksi serta distribusi produk; (5) pemasaran produk unggulan yang masih belum memanfaatkan teknologi informasi; dan (6) kurangnya Sumber Daya Manusia (SDM) dalam kegiatan produksi maupun distribusi.

Hambatan dan permasalahan yang ada dalam pemberdayaan masyarakat, salah satunya dalam pengembangan produk unggulan desa memerlukan strategi dan solusi yang tepat. Adapun solusi yang tepat dalam menangani permasalahan tersebut, yakni dengan menerapkan dan memanfaatkan teknologi sebagai upaya dalam peningkatan pemasaran produk unggulan desa. Pemanfaatan teknologi merupakan salah bentuk wujud adaptif untuk dapat bersaing dengan kompetitor yang lain dan merupakan sebuah sinergitas antara kemajuan zaman dengan kebutuhan pasar. Apalagi perkembangan sosial media telah mengubah perilaku dan gaya hidup seseorang, serta menimbulkan sebuah kelompok masyarakat baru di dunia maya, yakni masyarakat internet atau lebih dikenal dengan istilah netizen.

Peluang dan tantangan di era modern saat ini, harus mengubah masyarakat perdesaan untuk adaptif dengan perkembangan zaman. Era industri 4.0 mengharuskan civil society dapat memanfaatkan teknologi. Teknologi yang dapat diterapkan untuk membantu dalam pemasaran produk unggulan desa, yaitu dengan memanfaatkan (1) QR Code; dan (2) 
Facebook Marketplace. QR Code mempunyai banyak kelebihan, salah satunya mampu menyimpan semua jenis data, seperti data angka/numerik, alpanumerik, biner, kanji/kana. Selain itu, QR Code memiliki tampilan yang lebih kecil daripada barcode karena QR Code mampu menampung data secara horizontal dan vertikal, jadi secara otomatis ukuran dari tampilannya gambar QR Code bisa hanya sepersepuluh dari ukuran sebuah barcode. Tidak hanya itu, QR Code juga tahan terhadap kerusakan, sebab QR Code mampu memperbaiki kesalahan sampai dengan 30\% tergantung dengan ukuran atau versinya. Oleh karena itu, walaupun sebagian simbol QR Code kotor ataupun rusak, data tetap dapat disimpan dan dibaca (Novan, A.M., dkk,2016).

Pemanfaatan sosial media pun menjadi cara jitu untuk memasarkan sebuah produk. Hal tersebut sejalan dengan pendapat Chi (dalam Holly. P, 2013) yang menyatakan, bahwa ....defines social media marketing as a connection between brands and consumers. Artinya dengan memanfaatkan media sosial sebagai sarana promosi dapat mempertemukan antara produk dengan konsumen atau calon pembeli. Dengan demikian, pemanfaatan media sosial dapat membantu para penjual untuk mempromosikan dan menjual produknya kepada konsumen dengan mudah.

Dari pernyataan diatas dapat disimpulkan, bahwa dalam upaya peningkatan pemasaran produk unggulan desa diperlukan strategi pemasaran yang matang dan sesuai dengan kebutuhan pasar. Penerapan teknologi informasi menjadi salah satu harapan guna meningkatkan jumlah pendualan dari produk unggulan desa. Selain itu pendampingan dalam pengembangan produk unggulan desa tersebut diperlukan untuk menjadi katalis dalam proses pengembangan produk unggulan desa yang berkualitas.

Tujuan dari kegiatan pengabdian kepada masyakarakat ini adalah: (1) Menciptakan inovasi teknologi untuk mendorong pembangunan ekonomi di perdesaan, dan (2) Memberikan solusi berdasarkan kajian akademik atas kebutuhan, tantangan atau persoalan yang dihadapi masyarakat desa, baik secara langsung maupun tidak langsung.

\section{BAHAN DAN METODE}

Waterfall Model: Khalayak sasaran kegiatan pengabdian masyarakat ini adalah seluruh kelompok Usaha Mikro Kecil dan Menengah (UMKM), anggota Pos Pemberdayaan Keluarga (Posdaya), dan Badan Usaha Milik Desa(BUMDes) yang berada di wilayah Pemerintahan Desa Sukamaju Kecamatan Cihaurbeuti Kabupaten Ciamis.

Model proses yang digunakan adalah Waterfall Model dengan tahapan adalah sebagai berikut: 
1. Komunikasi (Communication). Pada tahap ini, dilakukan identifikasi masalah yang terjadi pada produk unggulan desa, dan dilakukan juga penyebaran kuesioner untuk mendapatkan data kebutuhan calon pembeli produk.

2. Perencanaan (Planning). Pada tahap ini, tujuan dan ruang lingkup pengabdian ditentukan agar pengabdian dapat berjalan dengan lebih terarah.

3. Pemodelan (Modelling). Pada tahap ini, dilakukan studi literatur dan pencarian sumber referensi yang mendukung landasan teori pengabdian, analisis pada sistem yang sedang berjalan sambil melakukan kajian mengenai kelemahan dan kelebihan sistem tersebut, menentukan usulan pemecahan masalah berdasarkan hasil kuesioner dan mengidentifikasi informasi yang akan ditampilkan pada aplikasi, serta melakukan perancangan sistem aplikasi dan rancangan awal user interface.

4. Konstruksi (Construction). Pada tahap ini, dilakukan pemrograman aplikasi berdasarkan rancangan sistem yang telah dibuat pada tahap selanjutnya.

5. Penyebaran (Deployment). Pada tahap ini, dilakukan uji coba terhadap aplikasi yang telah terintegrasi sesuai dengan rancangan yang telah dibuat, evaluasi berdasarkan user interface dan user acceptance test, serta membuat kesimpulan dan saran agar aplikasi dapat dikembangkan dengan lebih baik lagi.

Metode yang digunakan dalam pelaksanaan kegiatan pengabdian kepada masyarakat ini adalah sebagai berikut:

1. Pendataan

Pendataan dilakukan terhadap kelompok masyarakat yang bergerak dalam bidang UMKM dan masyarakat produktif yang telah bekerjasama dengan BUMDes.

2. Sosialisasi dan Edukasi

Sosialisasi dan edukasi dilakukan tentang pentingnya pemanfaatan teknologi informasi, khususnya berkaitan dengan QR Code yang berfungsi sebagai identitas digital dan Facebook Marketplace sebagai media promosi dan berjualan di era milenial.

3. Pembuatan QR Code dan akun Facebook Marketplace

Pembuatan QR Code dilakukan melalui website https:/www.the-qrcodegenerator.com/ dan untuk akun Facebook Marketplace menggunakan akun Facebook dari BUMDes.

4. Pelatihan pembuatan QR Code dan optimalisasi Facebook Marketplace

Pelatihan ini berorientasi pada tingkat kemahiran dari khalayak sasaran dalam pembuatan QR Code dan Facebook Marketplace secara online. 


\section{HASIL DAN PEMBAHASAN}

\section{Motivasi Khalayak Sasaran}

Setelah dilakukannya pendataan dan sosialisasi tentang digitalisasi produk unggulan Desa Sukamaju Kecamatan Cihaurbeuti Kabupaten Ciamis berbasis QR Code dan Facebook Marketplace, terdapat peningkatan motivasi masyarakat Desa Sukamaju Kecamatan Cihaurbeuti yang tadinya hanya 10\% untuk berwirausaha menjadi 90\%. Hal tersebut terlihat dari antusiasme peserta kegiatan yang hadir dalam acara tersebut. Selain itu, kegiatan tersebut dihadiri oleh Kepala Desa Sukamaju, para aparatur Desa Sukamaju, direktur dan anggota Badan Usaha Milik Desa (BUMDes), ketua dan anggota Posdaya, tokoh pemuda dan masyarakat, serta penggiat UMKM di Desa Sukamaju Kecamatan Cihaurbeuri Kabupaten Ciamis.

Selain itu, masyarakat menyadari kegiatan produktif melalui kewirausahaan dapat meningkatkan kesejahteraan masyarakat desa yang masih menjunjung tinggi kearifan dan budaya lokal. Ekonomi kerakyatan dan padat karya yang masih dipertahankan dalam budaya masyarakat desa menjadikan perekonomian masyarakat desa berjalan dengan baik. Selain itu, masyarakat sangat tertarik dengan adanya implementasi pemanfaatan teknologi informasi untuk kegiatan ekonomi masyarakat desa dan hal tersebut menjadi hal baru dalam upaya meningkatkan pemasaran produk unggulan desa tersebut.

\section{Digitalisasi Produk Unggulan Desa}

Produk unggulan di Desa Sukamaju di bawah pembinaan dan pengembangan BUMDes meliputi kopi robusta, teh hijau, abon cabe, gula semut dan madu. Semua produk tersebut menjadi produk unggulan Desa Sukamaju dan telah dikemas dengan kemasan yang sederhana. Setelah dilakukan kegiatan PKM yang pada tanggal 18 Februari 2019 di Aula Desa Sukamaju, dari pihak BUMDes akan mencantumkan QR Code sebagai bentuk dari digitalisasi produk unggulan desa. QR Code yang dibuat mencakup identitas asal produk, Contact Person dan QR Code dinamis yang mencantumkan link/Uniform Resource Locator (URL) dari akun resmi sosial media produk tersebut.

\section{Optimalisasi QR Code dan Facebook Marketplace}

Bentuk dari optimalisasi QR Code dan Facebook Marketplace, yakni dengan membuat QR Code secara online di website yang tidak berbayar dan hal ini menjadi inovasi untuk mengenalkan produk lokal atau desa kepada khalayak ramai secara digital. Hal tersebut juga menjadi langkah awal bagi BUMDes untuk mengoptimalkan pemanfaatan 
Digitalisasi Produk Unggulan Desa Sukamaju Kecamatan Cihaurbeuti Kabupaten Ciamis Berbasis QR Code dan Facebook Marketplace Irfan Nursetiawan, Kiki Endah, Ii Sujai

teknologi informasi, khususnya yang disediakan oleh platform dari Facebook yakni Facebook Marketplace. Facebook Marketplace merupakan salah satu fitur dari Facebook yang berfungsi bagi pengguna akun Facebook untuk berjualan secara daring dan dapat pula menjadi media promosi yang efektif untuk mendatangkan pelanggan. Adapun bentuk tampilan dari Facebook Marketplace dapat dilihat pada Gambar 1.

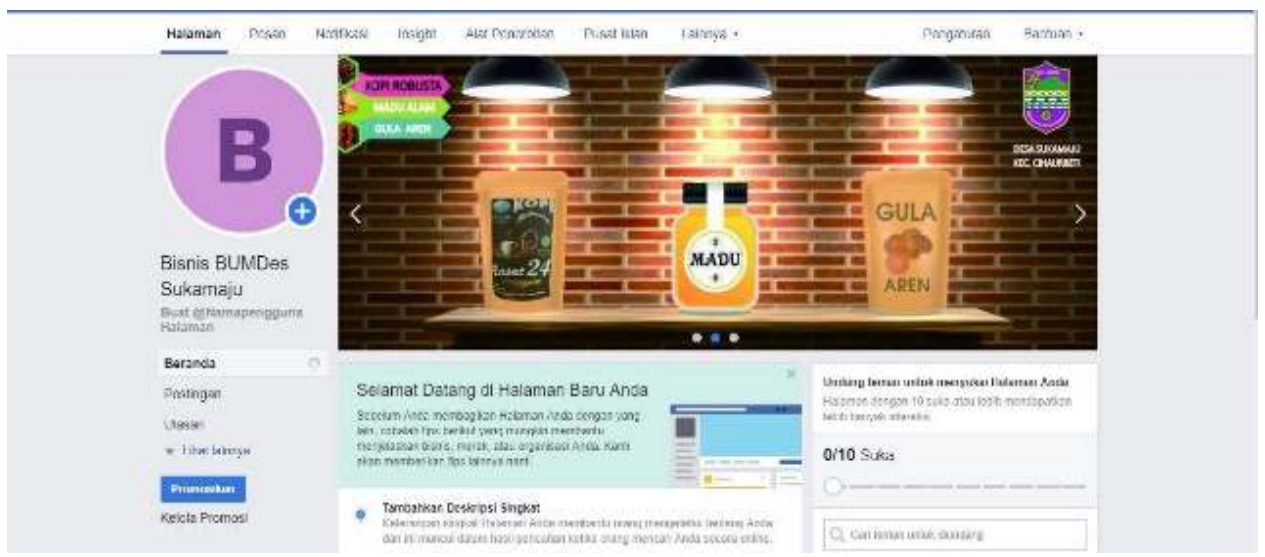

Gambar 1. Facebook Marketplace BUMDes Sukamaju

Berdasarkan tampilan Facebook Marketplace dari BUMDes Sukamaju tersebut berorientasi pada promosi produk lokal yang tentunya masih mengangkat nilai-nilai kearifan lokal. Produk yang ditampilkan di Facebook Marketplace tersebut diantaranya, kopi kemasan, teh kemasan, gula semut atau aren, dan madu hutan yang telah dikemas. Setelah dilakukan pembinaan dan bimbingan kepada direktur dan anggota BUMDes, serta masyrakat di Desa Sukamaju Kecamatan Cihaurbeuti maka Facebook Marketplace dapat dijadikan sebagai media promosi, publikasi, serta media berjualan melalui social media. Jangkauan calon pembeli maupun pelanggan dapat dengan mudah dilakukan. Selain itu, dengan adanya QR Code yang tercantum pada kemasan setiap produk, baik pembeli maupun penjual dapat mengetahui tentang identitas dari produk tersebut. Namun terdapat sedikit masalah, ketika implementasi QR Code dan Facebook Marketplace, yakni belum semua SDM di Desa Sukamaju mahir dalam menggunakan sosial media dan paham dalam mengimplementasikan pemanfaatan teknologi informasi

\section{KESIMPULAN DAN SARAN}

\section{Kesimpulan}

1. Motivasi masyarakat untuk berwirausaha dan memanfaatkan teknologi informasi meningkat setelah dilakukan kegiatan PKM tersebut. 
2. QR Code dapat digunakan sebagai media untuk promosi dan identitas sebuah produk yang tersimpan dalam sebuah gambar dua dimensi yang ditempatkan pada kemasan produk.

3. Facebook Marketplace dapat membantu kelompok UMKM dan BUMDes dalam memasarkan produk berbasis sosial media.

4. QR Code dan Facebook Marketplace merupakan digital platform yang dapat digunakan oleh khalayak ramai, khususnya masyarakat desa, tetapi perlu dimodifikasi dan dioptimalisasi yang mendukung pemasaran produk unggulan desa.

\section{Rekomendasi}

1. Pemerintah Desa harus meningkatkan sinyal dan kecepatan internet, sehingga akses internet dapat dengan mudah didapatkan oleh masyarakat di perdesaan.

2. Pemerintah daerah kabupaten/kota harus mendukung jangkauan layanan akses internet demi menghadapi era industri 4.0.

3. Peningkatan kualitas SDM perlu ditingkatkan melalui sosialisasi dan edukasi pemanfaatan teknologi informasi oleh akademis maupun para praktisi.

4. Inovasi kemasan produk unggulan desa harus disesuaikan dengan kebutuhan pasar dan kemajuan zaman.

5. Semua pihak dan para stakeholder harus bersinergi untuk meningkatkan produksi dan distribusi produk unggulan desa, sehingga dikenal serta diminati oleh semua orang

\section{DAFTAR PUSTAKA}

Akhmad Qashlim dan Hasruddin (2015). Implementasi Teknologi QR-Code untuk Kartu Identitas. Jurnal Ilmu Komputer.1.(2).1-6.

Bhinadi. A (2017). Penanggulangan Kemiskinan dan Pemberdayaan Masyarakat (Studi Kasus Daerah Istimewa Yogyakarta). Yogyakarta: CV. Budi Utama.

Christin. M (2018). Pengembangan Desain Produk Unggul IKM di Kabupaten Malang Jawa Timur yang Berdaya Saing Tinggi. Surabaya: Institut Teknologi Adhi Tama.

Eli. K (2012). Analisis Location Quotient dalam Penentuan Produk Unggulan pada Beberapa Sektor di Kabupaten Lingga Kepulauan Riau. Jurnal Integrasi 4(1): 31-46.

Ferdinand. A.L. Dkk. (2016). Aplikasi Penyedia Informasi Produk dan Penanda Stan pada Pameran Menggunakan QR Code Berbasis Android. Jurnal Teknik dan Ilmu Komputer 5(17): 91-108.

Holly. P (2013). Social Media as a Marketing Tool: A Literature Review. University of Rhode Island.Major Papers by Master of Science Students.1-26.

I Putu Astawa (2017). Pemberdayaan Desa Wisata Pinge Melalui Produk Unggulan Pariwisata Politeknik Negeri Bali. PNB: Bali.

Kominfo (2013). Kominfo: Pengguna Internet di Indonesia 53 Juta Orang. (Online). Tersedia: https://kominfo.go.id [08 Desember 2018]. 
Kompas (2016). Facebook Rilis Marketplace untuk Jual Beli Online. (Online) Tersedia: https://tekno.kompas.com [08 Desember 2018].

Novan, A.M., dkk (2016). Implementasi Quick Response (QR) Code pada Aplikasi Validasi Dokumen Menggunakan Perancangan Unified Modelling Language (UML). Jurnal Antivirus 10(1): 42-50.

Peraturan Pemerintah Nomor 43 tahun 2014 tentang Peraturan Pelaksanaan

Undang-undang Nomor 6 tahun 2014 tentang Desa.

Undang-undang Nomor 6 tahun 2014 tentang Desa. 